\title{
PENGEMBANGAN \\ MODUL PEMBELAJARAN MENULIS CERPEN BERMUATAN MOTIVASI BERPRESTASI UNTUK SISWA KELAS XI SMA
}

\author{
Ruli Andayani \\ e-mail: ruli.andayani@yahoo.co.id \\ Yuni Pratiwi \\ Endah Tri Priyatni \\ Universitas Negeri Malang
}

\begin{abstract}
Abstrak: Penelitian dan pengembangan ini bertujuan untuk mewujudkan bahan pembelajaran yang memiliki relevansi dengan kebutuhan belajar dan psikologis siswa. Penelitian dan pengembangan ini menghasilkan modul pembelajaran menulis bermuatan motif berprestasi untuk siswa kelas XI SMA/sederajat. Sebagai bahan belajar mandiri, modul berisi empat bagian utama: motivasi menulis cerpen, kegiatan memahami konsep diri, latihan menulis secara bertahap, dan kegiatan tindak lanjut. Modul dikembangkan berdasarkan model pengembangan Borg and Gall. Prosedur yang dilakukan terbagi dalam empat tahap utama, yakni studi pendahuluan, pengembangan draf modul, dan validasi kepada ahli dan praktisi, dan uji keefektifan.
\end{abstract}

Kata Kunci: pengembangan, modul, menulis cerpen, motivasi berprestasi

\begin{abstract}
This research is aimed to realizing teaching materials with relevance to the need of learning and students psychology. This research results a module of writing learning with an achievement motivation for the eleventh of senior hight school. As a self instruction, module contains of four main parts: motivation of writing short story, activity of understanding self-concept, writing gradually, and follow up activity. This module was developed based on the development model of Borg and Gall. The procedure used is divided into four stages: preliminary study, development of module draft and expert and practitioner validation and test of effectiveness.
\end{abstract}

Key Words: development, module, writing short story, achievement motivation

Penelitian dan pengembangan ini dilatarbelakangi oleh cita-cita untuk mewujudkan bahan pembelajaran yang memiliki relevansi dengan kebutuhan belajar dan psikologis siswa. Dalam hal ini pembelajaran menulis cerpen tidak sekadar disikapi sebagai materi untuk melatih keterampilan menulis secara teknis, tetapi juga mengarahkan siswa agar mampu menghayati nilai-nilai kehidupan di dalam cerpen yang direfleksikan dalam kehidupan sehari-hari, memiliki motivasi untuk belajar, dan menggerakkan siswa untuk melakukan suatu hal yang positif. Hal ini sesuai dengan fungsi sastra sebagai karya manusia yang indah dan berguna 
(dulce et etile). Horatius (dalam Teeuw, 1984:51) menyebutnya dengan istilah docere dan delectare, memberi ajaran dan kenikmatan; seringkali juga ditambah movere, menggerakkan pembaca pada kegiatan yang bertanggung jawab. Nurgiyantoro (2010:31) juga menyebutkan bahwa sastra berfungsi pragmatis bagi kehidupan sosial masyarakat. Sastra hadir untuk memberikan rasa senang dan memiliki manfaat dalam kehidupan karena dipersepsi sebagai suatu fakta sosial yang mampu menggerakkan emosi pembaca untuk bersikap dan berbuat.

Hal tersebut sesuai dengan hasil penelitian McClelland (1961:92) yang menyebutkan adanya hubungan cerita anak dan pertumbuhan ekonomi, yakni pertumbuhan ekonomi yang sangat tinggi selalu didahului oleh motivasi berprestasi (the need for achievement) yang tinggi dalam karya sastra masa itu. McClelland menyimpulkan bahwa cerita atau dongeng yang mengandung nilai $N$ Ach tinggi selalu diikuti pertumbuhan ekonomi yang tinggi di negara itu dalam kurun waktu 25 tahun kemudian.

Untuk mewujudkan cita-cita tersebut, penelitian dan pengembangan ini menghasilkan modul pembelajaran menulis bermuatan motivasi berprestasi untuk siswa kelas XI SMA/sederajat. Pemilihan muatan motivasi berprestasi dinilai relevan dengan karakteristik remaja yang sedang mencari konsep dirinya, mengenali minat, dan menggapai cita-citanya. Modul sebagai bahan belajar mandiri memiliki posisi penting untuk (1) memandu siswa dalam menulis cerpen dengan berbagai teknik yang menarik, (2) menyajikan model-model cerpen yang dapat memotivasi siswa dalam mencapai prestasi, dan (3) mendorong siswa agar memiliki keinginan bisa menulis cerpen sehingga kegiatan menulis di sekolah tidak disikapi sebagai kewajiban, tetapi sebagai kebutuhan berprestasi. Hal ini relevan dengan karakteristik modul sebagai sumber belajar (1) mandiri, (2) lengkap, (3) berdiri sendiri, dan (4) adaptif (Depdikbud, 2008:4-7; Daryanto dan Dwicahyono, 2014:186-188).

Sebagai bahan belajar mandiri, modul menulis cerpen berisi empat bagian utama. Keempat bagian tersebut adalah (1) motivasi menulis cerpen, (2) kegiatan memahami konsep diri, (3) latihan menulis secara bertahap (menentukan ide; mengembangkan kerangka alur cerita; membuat pembuka cerpen; mengembangkan alur menjadi cerita yang utuh; membuat bagian penutup; 
menyunting cerpen) berdasarkan konsep diri masing-masing, dan (4) kegiatan tindak lanjut, yakni penilaian diri dan publikasi karya.

Selama ini, belum ditemukan penelitian sejenis yang berusaha mengembangkan modul menulis cerpen dengan menanamkan muatan motivasi berprestasi di dalamnya. Hanya saja, penelitian yang berkaitan dengan motivasi berprestasi pernah dilakukan oleh Engester, dkk. (2009), yaitu dengan membandingkan muatan motivasi berprestasi di dua negara federal Jerman: Baden-Württemberg dan Bremen pada buku pelajaran yang digunakan oleh siswa SD dan SMP. Hasil penelitian ini menyebutkan bahwa citra motivasi berprestasi yang lebih tinggi dalam buku pelajaran di Württemberg selalu diikuti oleh hasil PISA (Program for International Student Assessment) yang tinggi dan perkembangan bangsa yang tinggi pula, sedangkan di Bremen justru terjadi sebaliknya. Hasil penelitian ini tentu saja memberikan sumbangan yang positif bagi perkembangan dunia pendidikan, khususnya pengembangan buku teks. Akan tetapi, Engester, dkk. belum (1) menyelidiki keterlibatan buku bacaan siswa di luar buku pelajaran dalam mempengaruhi hasil PISA dan perkembangan bangsa di negara federal tersebut, (2) faktor-faktor lain yang dimungkinkan ikut mempengaruhi, dan (3) melakukan penelitian lanjutan yang berusaha menguji keefektivan buku teks bermuatan motif berprestasi tersebut dengan hasil belajar siswa secara langsung.

Jika penelitian Engester, dkk. masih sebatas menyelidiki keterkaitan antara motivasi berprestasi dan hasil PISA, penelitian dan pengembangan modul ini dapat dikatakan sebagai lanjutan dari penelitian tersebut sebab berupaya untuk mengembangkan modul pembelajaran menulis cerpen yang secara praktis diyakini dapat meningkatkan hasil belajar (keterampilan) siswa dalam menulis cerpen. Dengan modul ini, siswa diberi ruang untuk (1) mengenali konsep dirinya, (2) mengemas konsep diri tersebut menjadi ide penulisan cerpen, (3) memperoleh dorongan yang kuat dalam diri untuk menulis cerpen, dan (4) mengusai teknik menulis cerpen. Dengan demikian, dari hasil penelitian dan pengembangan ini diharapkan dapat menghasilkan modul pembelajaran yang relevan dan efektif sesuai dengan tujuan pembelajaran menulis cerpen yang diharapkan. 


\section{METODE}

Model penelitian dan pengembangan menggunakan model penelitian dan pengembangan yang dikembangkan oleh Borg dan Gall. Menurut Borg dan Gall (1983:772), educational research and development $(R \& D)$ is a process used to develop and validate educational production. Dengan pengertian ini, rangkaian langkah-langkah penelitian dan pengembangan dilakukan secara siklis dan pada setiap langkah yang akan dilalui atau dilakukan selalu mengacu pada hasil langkah sebelumnya hingga pada akhirnya diperoleh suatu produk yang baru.

Tahap-tahap penelitian dan pengembangan yang dikemukakan oleh Borg dan Gall di atas terdiri atas sepuluh langkah, tetapi pada pengembangan modul ini, langkah-langkah tersebut dikelompokkan menjadi empat tahap, yaitu tahap pertama tahap studi pendahuluan atau (1) research and information collecting, tahap kedua adalah pengembangan draf modul yang meliputi dua kegiatan, yakni kegiatan (2) planning dan (3) develop preliminary form of product, tahap ketiga yakni validasi modul yang terdiri atas empat kegiatan (4) preliminary field testing, (5) main product revision, (6) main field testing, (7) operational product revision, dan tahap ketiga yakni uji keefektifan yang meliputi tiga kegiatan: (8) operational field testing, (9) final product revision, (10) dissemination and implementation.

Pada tahap prapengembangan dilakukan studi pendahuluan, analisis kesulitan siswa belajar, analisis kebutuhan modul menulis cerpen, dan penulisan cerpen. Untuk mengetahui tingkat keterbacaan cerpen, dilakukan uji keterbacaan dengan teknik tes cloze pada kelompok kecil (sepuluh siswa kelas XI SMA) yang dipilih secara acak. Berdasarkan data dan informasi yang diperoleh dari kegiatan analisis pada tahap prapengembangan, selanjutnya dilakukan kegiatan penyusunan Rencana Pelaksanaan Pembelajaran (RPP) dan modul. Draf modul yang selesai disusun selanjutnya divalidasi dilakukan untuk mengumpulkan data yang terkait dengan kekuatan dan kelemahan modul. Validasi ini melibatkan kelompok ahli dan praktisi. Validasi ahli melibatkan ahli prosa fiksi dan ahli pembelajaran menulis cerpen, sedangkan validasi praktisi melibatkan guru Bahasa Indonesia jenjang SMA dan motivator. 
Tahap uji coba dilakukan di XI SMAN 1 Boyolangu, Tulungagung dengan melibatkan 29 siswa. Pada akhir pembelajaran, siswa diminta untuk menulis cerpen dan mengisi angket untuk mengetahui kesan siswa terhadap modul. Skor dari cerpen tulisan siswa selanjutnya dijadikan sebagai pedoman dalam menilai keterlaksanaan modul, sedangkan angket kesan siswa digunakan sebagai bahan pertimbangan untuk merevisi modul. Berdasarkan hasil uji coba modul ini, selanjutnya dilakukan revisi modul sehingga diperoleh produk jadi berupa modul yang siap diimplementasikan dalam konteks yang lebih luas.

Data dalam penelitian ini berupa data numerik dan data verbal. Data numerik diperoleh dari hasil penilaian validator terhadap modul yang dikembangkan. Sementara itu, data verbal diperoleh ketika konsultasi validasi berlangsung, baik secara lisan maupun tulis. Data yang telah dihimpun dianalisis secara kualitatif dan kuantitatif. Analisis data verbal dilakukan secara kualitatif, yakni (1) mengumpulkan data verbal tertulis yang diperoleh dari angket penilaian, (2) mentranskrip data verbal lisan, (3) menghimpun, menyeleksi, dan mengklasifikasi data verbal tulis dan hasil transkrip verbal lisan berdasarkan kelompok uji, dan (4) menganalisis data dan merumuskan simpulan analisis sebagai dasar untuk melakukan tindakan: revisi atau implementasi dengan pedoman pemaknaan data yang diadaptasi dari Akbar (2013:78-82). Selanjutnya, analisis data numerik dilakukan secara kuantitatif, yakni dengan menggunakan analisis statistik menggunakan program SPSS.

\section{HASIL DAN PEMBAHASAN}

\section{Deskripsi Modul yang Dikembangkan}

Penelitian dan pengembangan ini berhasil mengembangkan modul pembelajaran menulis cerpen yang digunakan untuk siswa kelas XI SMA atau sederajat. Karakteristik yang khas dalam modul ini yakni munculnya muatan motivasi berprestasi di dalam modul. Modul ini menyajikan cerpen-cerpen bermuatan motivasi berprestasi dengan tema-tema permasalahan khas remaja (tingkat SMA dan sederajat) dalam mencapai prestasi. Oleh karena itu, pengembangan cerita dan bentuk bahasa yang digunakan disesuaikan dengan tingkat perkembangan remaja. 
Cerpen bermuatan motivasi berprestasi yang disajikan di dalam modul paling tidak memiliki lima karakteristik yang menonjol. Pertama, cerpen menampilkan kisah remaja dengan masalah atau konflik khas yang dialami oleh remaja dalam mewujudkan mimpi, harapan, cita-cita, ideologi, atau minatnya. Kedua, cerpen menampilkan kegigihan tokoh dalam menyelesaikan masalahnya secara kritis dan kreatif. Ketiga, cerpen menampilkan sikap tokoh dengan konsep diri yang dipegang teguh: percaya diri, menyukai tantangan, berinisiatif, dan berani mencoba. Keempat, cerpen menampilkan ketelatenan dalam pengolahan konflik sehingga tidak ada penyelesaian masalah yang tiba-tiba (penuh keajaiban, kemustahilan, atau kebetulan). Kelima, menginspirasi remaja untuk meyakini, memiliki, dan mewujudkan mimpi, harapan, cita-cita, ideologi, atau minat masing-masing.

Cerpen Sketsa Mimpi Boni yang disajikan pada bab II bergenre konvensional, artinya cerpen ini dikembangkan dengan pola alur yang umum dan pengembangan cerita, serta gaya bahasa yang mudah dipahami oleh siswa tingkat SMA dan sederajat. Cerpen ini mengisahkan perjuangan seorang remaja yang ingin mempertahankan hobi dan minatnya dalam bidang desain grafis ketika mendapat tekanan dari orangtua untuk menekuni bidang sains dan teknologi. Cerpen Tangga Nada Violina mengisahkan perjuangan seorang gadis tunarungu dalam bermain biola meskipun sering mendapat penolakan dan diskriminasi dari teman-teman di sekolahnya. Cerpen inilah yang disajikan secara liris sehingga tingkat kesulitannya sedikit lebih tinggi dibandingkan dengan cerpen sebelumnya. Cerpen terakhir, Percakapan Dua Organ, mengisahkan seorang remaja yang aktif dalam gerakan antinarkoba. Tokoh utama cerpen ini adalah jantung dan paru-paru yang diilustrasikan secara personifikasi. Pengolahan konflik, latar, dan bentuk dialog bernuansa ilmiah (fiksi sains) sehingga memiliki tingkat kesulitan yang lebih tinggi dibandingkan dengan cerpen yang sebelumnya. Dilihat dari isinya, ketiga teks cerpen yang disebut sebelumnya memiliki muatan motivasi berprestasi di dalamnya. Selain muatan tersebut, ketiga cerpen yang digunakan juga telah memenuhi empat kriteria yang lain, yakni keotentikan, tingkat kesulitan, kebermanfaatan, dan kemenarikan. 
Selain tampak dalam cerpen, muatan motivasi berprestasi juga tampak dalam sajian materi, bentuk kegiatan pembelajaran, dan gambar ilustrasi yang digunakan. Motivasi berprestasi tampak pada sajian materi setiap bab, yakni dengan digunakannya kalimat-kalimat mutiara yang memiliki daya persuasif dalam memotivasi siswa untuk menulis cerpen.
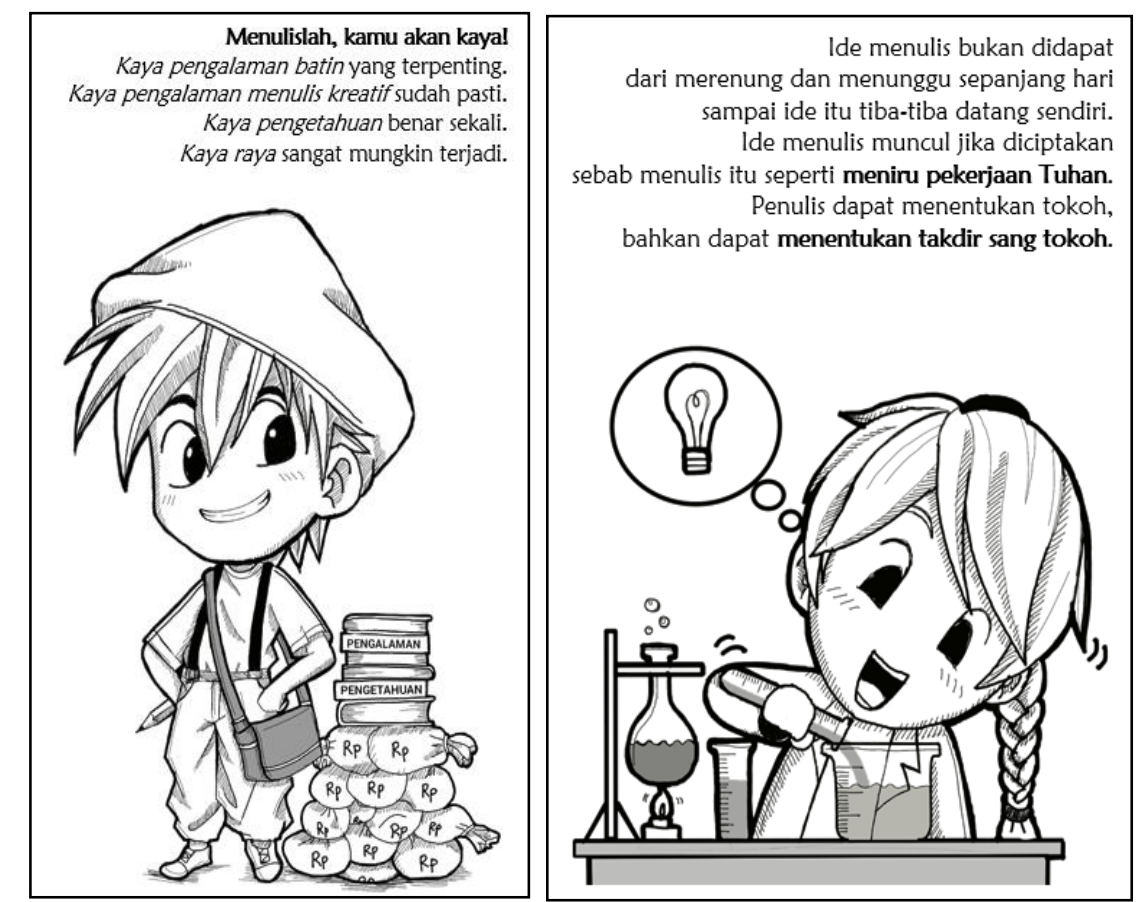

Gambar 1. Ilustrasi Setiap Bab pada Modul

Modul dicetak dalam kertas HVS ukuran B5 (175 x $250 \mathrm{~mm})$ dengan ketebalan 100 gram. Tampilan tata letak pada kulit muka, belakang, dan punggung menggunakan kombinasi warna peach, biru, hijau, dan kuning cerah. Penulisan teks utama menggunakan jenis huruf maindra GD $11 \mathrm{pt}$, sedangkan penulisan teks kutipan menggunakan jenis huruf candara 11 pt. Untuk sajian sampul, digunakan variasi jenis huruf flubber, avant que, CF poidpolaroid, dan absicca. Berikut disajikan gambar sampul modul yang dikembangkan. 


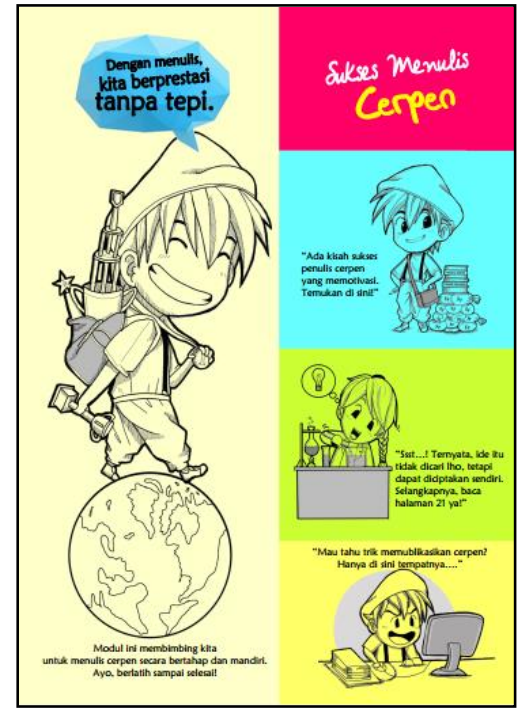

Gambar 2. Sampul Belakang Modul

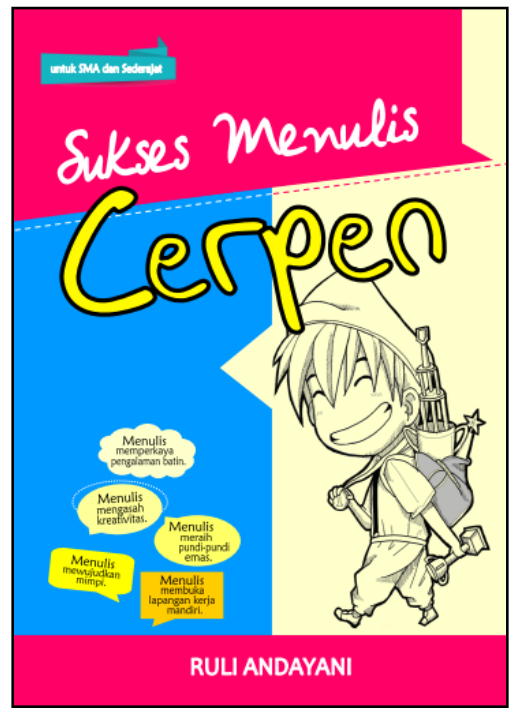

Gambar 3. Sampul Depan Modul

\section{Hasil Uji Keefektifan Produk}

Berdasarkan hasil validasi dan uji coba, modul dapat dinyatakan layak untuk diimplementasikan karena hasil validasi dengan ahli prosa-fiksi, ahli pembelajaran menulis cerpen, ahli pengembangan modul, dan guru menunjukkan 90\%. Hal ini berarti modul sangat layak untuk diimplementasikan. Sementara itu, hasil validasi dengan motivator mencapai $80,5 \%$ yang artinya juga masih layak diimplementasikan hasil dan hasil uji lapangan menunjukkan bahwa tingkat kebertiramaan modul mencapai $87 \%$. Hal ini diperkuat dengan tanggapantanggapan positif dari siswa subjek uji. Modul yang dihasilkan memang tidak terlepas dari kekurangan, tetapi berdasarkan koreksi kritis dan masukan dari berbagai pihak, baik ahli, praktisi, maupun siswa, modul telah direvisi dan disempurnakan sehingga sudah siap untuk diimplementasikan dalam pembelajaran menulis cerpen.

Dari hasil analisis statistik uji beda keterampilan menulis cerpen sebelum dan setelah perlakuan diketahui bahwa $\mathrm{t}=18,029$ dengan taraf signifikansi 0,000 $(\mathrm{p}<0,05)$. Nilai t (positif) menunjukkan bahwa mean postes lebih besar daripada pretes. Dengan demikian, dapat disimpulkan bahwa terdapat perbedaan yang signifikan antara skor menulis cerpen sebelum dan sesudah perlakukan karena $\mathrm{p}<0,05$. Artinya, terdapat peningkatan skor siswa dalam menulis cerpen setelah menggunakan modul menulis cerpen yang dikembangkan. 
Jika diperiksa kembali, peningkatan skor cerpen siswa dipengaruhi oleh perubahan gaya penulisan siswa yang semakin meningkat. Perubahan tersebut tampak pada pemilihan tema, pembuatan judul, bentuk bagian pembuka cerpen, cara mengembangkan cerpen, dan tata tulis cerpen.

Tema-tema yang diangkat sebelum menggunakan modul lebih banyak pada tema cinta dengan konflik yang kurang jelas, sedangkan tema-tema yang diangkat sesudah menggunakan modul lebih banyak tema motivasi diri dengan pengolahan konflik yang dramatis. Hal ini membuktkan bahwa siswa mengikuti dengan baik langkah menulis cerpen dan materi yang disajikan dalam modul.

Pembuatan judul cerpen mengalami perubahan yang sangat berarti. Sebelumnya, siswa lebih senang memilih judul dengan pilihan kata yang singkat dan tidak menimbulkan penasaran bagi pembaca. Misalnya, sebelum menggunakan modul, judul yang dipakai Persahabatan; Suatu Saat Nanti; Malam itu, Survivor; Sang Pahlawan. Lain halnya ketika pembelajaran menulis cerpen sudah selesai, judul-judul cerpen tampak lebih menarik dan menimbulkan rasa penasaran bagi pembaca: Malaikat Merah, Gagak Tak Bersayap, Hitam Putihnya Hitam, Mendaki Matahari, dan sebagainya

\section{Kajian Produk}

Modul hasil penelitian dan pengembangan ini memiliki kemenarikan, baik dari sisi muatan, tampilan, maupun pilihan warna yang digunakan. Dari sisi muatan cerpen yang disajikan, modul ini memiliki daya yang kuat untuk memotivasi pembacanya, khususnya dalam hal menulis cerpen. Bentuk modul mendukung terwujudnya bahan ajar yang berdaya, sebagaimana pernah diteliti oleh McClelland (1961:90-92) dan Engester (2009:111-112). Karakter tokoh di dalam cerpen yang memiliki motivasi kuat untuk meraih prestasi, secara tidak langsung, memberi kesempatan kepada pembaca untuk mengidentifikan dirinya sesuai dengan isi bacaan.

Pada dasarnya manusia mengidentifikasikan dirinya berdasarkan persepsinya terhadap lingkungan. Remaja yang tumbuh di lingkungan yang baik memiliki karakter yang baik. Remaja yang tumbuh di lingkungan senang membaca tumbuh sebagai remaja yang gemar membaca. Remaja yang sering 
mendengarkan lagu-lagu cengeng dan pesimis seringkali membuat suasana hatinya menjadi sendu. Remaja yang sering menonton sinema yang mencitrakan kekerasan remaja akan membuat pribadinya menjadi keras. Remaja dididik dengan kata-kata yang baik (positif) tumbuh sebagai remaja yang santun dan terjaga ucapannya. Oleh karena itu, bacaan yang baik juga akan dipersepsikan dengan baik di dalam diri remaja, seperti halnya kekuatan positif novel Ayat Ayat Cinta (2007) yang mampu memotivasi pembacanya menjadi lebih religius, bahkan sampai mengidentifikasikan dirinya sebagai tokoh dalam novel (Fahri dan Aisyah). Dengan demikian, modul yang dikembangkan dengan muatan motivasi berprestasi ini juga semakin menguatkan fungsi pragmatik sastra (Teeuw, 1984:51) yang indah, bermanfaat, dan menggerakkan pembaca untuk meraih prestasi sesuai dengan minat masing-masing individu. Prestasi dalam menulis cerpen adalah hal pertama. Selanjutnya, prestasi yang digambarkan dalam masingmasing cerpen. McClelland (1961) berpendapat bahwa motivasi berprestasi yang muncul di lingkungan seseorang tumbuh dapat mempengaruhi motivasi berprestasi seseorang tersebut. Dengan hal ini, lembaga pendidikan memiliki kewajiban untuk menciptakan lingkungan belajar dengan iklim akademik yang mendorong siswa untuk meraih prestasinya, salah satunya yakni dengan menyediakan modul seperti ini.

Dari sisi tampilan, modul ini memiliki pertimbangan yang matang. Setiap warna memiliki kesan dan efek tersendiri bagi pembaca. Seorang pengembang modul dan bahan ajar yang lain memang perlu mempertimbangkan filosofi setiap warna karena sedikit banyak warna dapat mempengaruhi efek pembelajaran yang dilakukan.

Berdasarkan cara pandang ilmu psikologi, warna biru muda yang digunakan dalam modul ini dapat membantu menenangkan pikiran dan meningkatkan konsentrasi belajar. Warna hijau menciptakan rasa tenang segar, dan emosi yang seimbang. Walaupun warna hijau tidak mendominasi modul ini, keberadaannya ikut menyeimbangkan warna-warna yang lain. Warna kuning mengandung makna optimis, semangat, dan ceria. Warna kuning sangat baik digunakan untuk membantu penalaran secara logis dan analitis, mendorong adanya ide-ide kreatif dan original. Warna peach (merah mengarah ke warna pink tua kemerah-merahan) 
memberi kesan berani dan ceria. Warna merah memiliki kesan bersemangat, enerjik, dinamis, komunikatif, aktif, dan gembira. Oleh karena itu, warna merah mampu digunakan untuk menarik perhatian siswa untuk belajar. Pemilihan warna warna merah ini tentu masih mampu mendukung misi modul yang ingin menonjolkan muatan motivasi berprestasi di dalamnya.

Berkaitan dengan muatan motivasi berprestasi yang ditonjolkan, modul ini sangat relevan dengan perkembangan psikologis siswa SMA. Cerpen-cerpen yang bermuatan seperti ini diyakini dapat mempengaruhi tindakan siswa sebagai sasaran pembacanya. Motivasi berprestasi untuk menulis cerpen merupakan salah satu bentuk kebutuhan aktualisasi diri, sebagaimana disampaikan oleh Maslow (dalam Schunk, 2012:483-486). Aktualisasi diri terwujud dalam kebutuhan untuk menjadi apa pun yang bisa dilakukan seseorang. Seseorang yang memiliki ingin mengatualisasikan dirinya menunjukkan ketertarikan yang besar pada cara mencapai tujuan. Seseorang dapat dikatakan memiliki motivasi berprestasi yang tinggi jika dari dalam dirinya ada dorongan atau keinginan yang kuat untuk melakukan atau menghasilkan suatu karya dan berprestasi lebih baik dari prestasi yang pernah diraih orang lain. Seseorang yang memiliki motivasi berprestasi tinggi cenderung bekerja lebih keras pada tugas-tugas tertentu; belajar lebih cepat; melaksanakan pekerjaan sebaik-baiknya jika pekerjaan itu menantang prestasi. Dengan adanya modul bermuatan motivasi berprestasi ini diharapkan dapat menggerakkan siswa melakukan tindakan positif, khususnya dalam hal yang pencapaian prestasi.

Modul ini memberikan kesempatan kepada siswa untuk mengerjakan latihan-latihan menulis yang bermakna. Pembelajaran dilakukan dengan memberikan pengalaman bermakna kepada siswa melalui proses mengalami (belajar menulis cerpen). Melalui modul ini, siswa diajak mempraktikkan menulis cerpen, bukan sekadar belajar tentang menulis cerpen atau sekadar teori cerpen. Praktik menulis dilakukan secara bertahap sehingga siswa mampu menulis secara kreatif setiap detail bagian cerpen yang memungkinkan dapat dieksplorasi. Dengan modul ini, siswa benar-benar diberi ruang untuk menemukan ide cerita yang 'istimewa' yakni dengan mengindentifikasi motivasi berprestasi pada diri sendiri dan mengembangkannya menjadi bahan menulis cerpen; membuat judul 
yang menarik perhatian pembaca; membuat bagian pembuka yang memukau dan menimbulkan rasa penasaran bagi pembaca; mengembangkan ide secara konsisten dan dramatik; membuat bagian penutup cerpen yang tidak terduga; menyunting. Dengan demikian, pengalaman siswa menjadi utuh. Siswa tidak sekadar mengetahui, tetapi juga melakukan.

Dilihat dari kelebihan-kelebihan yang dimilikinya, modul yang dikembangkan berpeluang difungsikan untuk memecahkan masalah dalam pembelajaran menulis cerpen. Dengan modul ini, pembelajaran menulis cerpen yang selama ini cenderung pasif karena siswa tidak dilibatkan secara langsung untuk menulis, menjadi lebih aktif melalui kegiatan menulis secara bertahap. Pembelajaran menjadi lebih bermakna dengan menghasilkan karya yang nyata. Sebagai pengaruh jangka panjang, jika pembelajaran menulis cerpen di sekolah berhasil dengan baik, bukan hal mustahil terwujudnya industri kreatif yang bersumber dari karya sastra. Penerbitan buku, yang salah satunya dapat berbentuk kumpulan cerpen, adalah bagian dari industri kreatif yang potensial untuk dikembangkan, mengingat kreativitas menjadi keterampilan yang perlu dimiliki dalam menyongsong abad ke-21 yang sangat kompetitif.

Sementara itu, muatan motivasi berprestasi dalam modul dapat memberi corak yang khas dan kuat pada perkembangan bahan ajar di Indonesia. Bahan ajar menjadi lebih berkarakter dan sejalan dengan cita-cita mulia pemerintah dalam mewujudkan generasi emas. Cita-cita ini akan sulit terwujud jika tidak dimulai dengan sikap positif dari setiap individunya. Motivasi untuk berkarya, berkreasi, dan berprestasi harus ditanamkan kepada setiap siswa. Modul ini mewadahi citacita mulia tersebut dengan menyajikan muatan motivasi berprestasi di dalamnya.

Akan tetapi, terlepas dari kelebihan-kelebihan yang dimiliki, modul yang dikembangkan memiliki kelemahan yang perlu disikapi dengan baik dalam praktik pembelajaran di kelas. Perlu diingat bahwa praktik pembelajaran di Indonesia masih berbentuk rombongan belajar yang setiap siswanya belum tentu memiliki kemampuan yang homogen. Padahal, karakteristik pembelajaran dengan modul adalah siswa dapat belajar dengan kecepatan masing-masing. Siswa dengan kecepatan belajar yang tinggi tidak perlu menunggu siswa dengan kecepatan belajar yang rendah. Begitu juga dengan siswa dengan kecepatan belajar yang 
rendah tidak perlu disamakan waktu belajar dan kompetensinya. Siswa dapat melanjutkan materi jika kompetensi prasyarat sudah dituntaskan tanpa saling menunggu. Oleh karena itu, diperlukan modul penunjang untuk mewadahi kedua siswa tersebut, yakni modul pengayaan untuk siswa yang memiliki kecepatan belajar tinggi dan modul remedial untuk siswa yang memiliki kecepatan belajar rendah. Modul penunjang ini diperlukan jika kondisi siswa memiliki kemampuan belajar yang heterogen. Sebaliknya, jika siswa dalam satu kelas memiliki kemampuan yang homogen, pembelajaran dapat dilaksanakan cukup dengan satu modul utama sebagaimana yang dikembangkan dalam penelitian ini. Modul yang dihasilkan memang tidak terlepas dari kekurangan, tetapi berdasarkan koreksi kritis dan masukan dari berbagai pihak, baik ahli, praktisi, maupun siswa, modul telah direvisi dan disempurnakan sehingga sudah siap untuk diimplementasikan dalam pembelajaran menulis cerpen.

\section{PENUTUP}

Modul yang dikembangkan dapat dimanfaatkan oleh siswa sebagai bahan latihan menulis cerpen yang mandiri, baik di sekolah maupun di rumah. Materi yang lengkap dalam modul ini dapat dipelajari pada tempat dan waktu yang fleksibel. Siswa dianjurkan agar membaca modul ini sebelum pertemuan di sekolah agar siswa memiliki skemata yang cukup. Sementara itu, guru dapat memantau kegiatan kreatif menulis cerpen yang ketika pembelajaran berlangsung. Posisi guru dalam modul ini adalah sebagai fasilitator, motivator, dan inspirator. Ketika materi sudah tersedia dengan dilengkapi contoh dan latihan yang mudah diikuti, serta penilaian diri yang mampu memberi ruang siswa untuk belajar mandiri, guru harus bertindak sebagai fasilitator yang selalu siap membantu dan membimbing siswa, motivator untuk terus memacu semangat belajar siswa, dan sebagai inspirator yang menjadi teladan dalam penulisan cerpen. Dengan demikian, akan tercipta sebuah modulasi belajar yang mengagumkan.

Hasil penelitian dan pengembangan selanjutnya dapat didiseminasikan dalam jurnal ilmiah, baik tercetak maupun online dan dalam forum MGMP. Untuk pengembangan produk lebih lanjut, modul dapat diintergrasikan dengan kompetensi dasar lain, misalnya kompetensi dasar memahami, membandingkan, 
mengonversi teks cerpen menjadi teks yang lain, dan sejenisnya sehingga dihasilkan produk yang utuh berkaitan dengan cerpen. Selain itu, modul juga dapat dilengkapi dengan perangkat pembelajaran lain dikembangkan secara berjenjang. Modul disusun untuk tiga jenjang pendidikan, yakni jenjang SD, SMP, dan SMA dengan tingkat kesulitan, kedalaman, dan bahasa yang berbeda sesuai dengan tingkat perkembangan psikologis dan perkembangan siswa setiap jenjang. Dengan demikian, modul ini akan lebih sempurna dan mampu mewadahi kreativitas siswa secara berkelanjutan.

\section{DAFTAR RUJUKAN}

Akbar, S. 2013. Instrumen Perangkat Pembelajaran. Bandung: PT Remaja Rosdakarya.

Borg dan Gall, 1983. Educational Research: An Introduction. New York: Longman.

Daryanto dan Dwicahyono. 2014. Pengembangan Perangkat Pembelajaran (Silabus, RPP, PHB, Bahan Ajar). Yogyakarta: Penerbit Gava Media.

Depdiknas. 2008. Teknik Penyusunan Modul. Materi Bimtek tidak Diterbitkan, (Online), (staff.uny.ac.id/sites/default/files/teknik-penyusunanmodul.pdf.), diakses tanggal 2 Februari 2015.

Engester, S., Falko Rheinberg, dan Matthias Möller. 2009. Achievement Motive Imagery in German Schoolbooks: A Pilot Study Testing McClelland's Hypothesis. Journal of Research in Personality, 43 (1). (Online), (www.elsevier.com/locate/jrp, diakses 4 September 2014).

Nurgiyantoro, B. 2009. Teori Pengkajian Fiksi. Yogyakarta: Gadjah Mada.

McClelland, D.C. 1961. The Achieving Society. Princeton, NJ: Van Nostrand.

Schunk, D.H. 2012. Teori-Teori Pembelajaran: Perspektif Pendidikan. Terjemahan oleh Eva Hamdiah dan Rahmad Fajar. 2012. Yogyakarta: Pustaka Pelajar.

Teeuw, A. 1984. Sastra dan Ilmu Sastra: Pengantar Teori Sastra. Jakarta: PT Dunia Pustaka Jaya. 